ELORE (ISSN 1456-3010), vol. $16-1 / 2009$.

Julkaisija: Suomen Kansantietouden Tutkijain Seura ry.

[http://www.elore.fi/arkisto/1_09/pk_1_09.pdf]

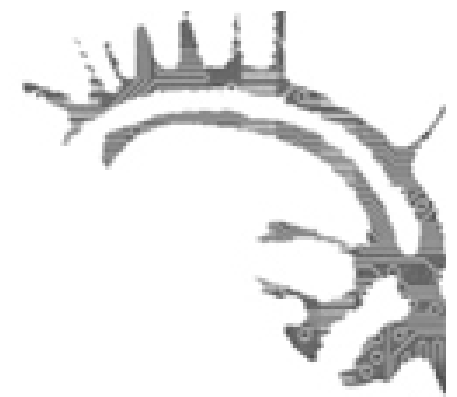

\title{
PäÄKirjoitus: 15 Vuotta VapaAsti SaAtavilla
}

\section{Petja Aarnipuu ja Riina Haanpää}

Elore on, kuten monet jo tietävätkin, vapaan saatavuuden verkkolehtien pioneeri Suomessa. Ensimmäinen Elektroloristi ilmestyi vuonna 1994. Numeron 1/1994 pääkirjoituksessa [http://www.elore.fi/arkisto/1_94/poy.194.html] Jyrki Pöysä valottaa lehden genealogiaa ja tarjoaa käyttöohjeita maassamme täysin uudentyyppisen julkaisun hankintaan ja lukemiseen. Vaihtoehtoja löytyi: paperiprintti oli saatavilla SKS:n etnologisessa kirjastossa ja Helsingin yliopiston pääkirjastossa, sähköisen version sen sijaan voi tilata itselleen sähköpostina. Sen saattoi kyllä myöskin ladata omalle levykkeelleen "toimittajien tykönä tai pitämällä yllä ystävällisiä suhteita niihin, joilla Elektroloristi jo on". WWW:n käyttö julkaisukanavana oli tuolloin jo näköpiirissä, mutta ei vielä ajankohtainen, koska World Wide Web oli vasta harvojen ulottuvilla.

Eikös 1994 ollut vasta äsken, vanhempi lukija kysyy nyt itseltään. No, ensi syksyn nuorimmat folkloristiikan fuksit olivat tuolloin noin 3-vuotiaita. Tässä yhtaikaa sekä lyhyessä että pitkässä ajassa Elektroloristista on tullut Elore, uuden ajan innovaatiosta akateemista arkipäivää ja suomalaisesta folkloristiikan alan tieteellisesti korkeatasoisesta julkaisusta sellainen, että sitä on teknisesti mahdollista lukea joka savussa, johon nettiyhteys on ulotettu.

Eloren potentiaalinen levikki on siis hyvin laaja, sen volyymi on suuri ja taso korkea. Näitä voisi kuvitella mainesanoiksi, jotka ihminen mielellään laittaisi paperiin esimerkiksi lehden julkaisemiseen tarvittavaa tukirahaa hakiessaan. Niin ajateltiin myös Eloren toimituksessa ja Elorea julkaisevassa Suomen Kansantietouden Tutkijain Seurassa, kun laadimme tavalliseen tapaan julkaisutukihakemusta Tieteellisten Seurain Valtuuskunnalle. TSV on tukenut Elorea vuosittain 5000 eurolla jo alkuvuodesta 2006. Tämän valtionavustuksen turvin Elorelle on palkattu toimitussihteeri ja lehti on julkaistu kaksi kertaa vuodessa. Sen erinomainen toimituskunta on koottu yhtä usein Suomen yliopistoista saman vaatimattoman kahvipöydän ääreen arvioimaan mennyttä ja suunnittelemaan tulevaa. Elorea on lisäksi jatkuvasti kehitetty ja uudistettu Opetusministeriön vapaan saatavuuden eli open access -ideologian mukaisesti - onhan tiedon 


\section{Vuotta Vapaasti Saatavilla}

vapaa kulku meidän humanistienkin parhaiden perinteiden ja ihanteiden mukaista. Suurin osa Eloren eteen tehdystä työstä on kuitenkin akateemista tietotalkoota yhteiseksi hyväksi, CV-merkintäpalkalla (humanististen perinteiden ja ihanteiden mukaista sekin, parhaudesta jääköön nyt sanomatta mitään).

Tänä keväänä saimme iskun vyön alle: TSV pudotti Eloren julkaisutuen alle puoleen. Haetun ja kolmena perättäisenä vuotena saadun 5000 euron sijaan meille myönnettiin tukea 2300 euroa. Seuran pieneen kokoon nähden lehti on kuulemma liian suuri. Vapaa saatavuus merkitsee nollaa euroa tilausmaksuja eli ei yhtään myynnistä saatavaa rahoitusta, ei hyvä. Ja alun viisi tonnia oli sitä paitsi akuuttia tukirahaa jotta kaatumisen partaalla keikkunut lehti saataisiin jaloilleen - tästä starttirahaluonteesta tosin ei missään vaiheessa mainittu Eloren toimittajille tai SKTS:lle.

Mikä nyt eteen? Epävarmuus, josta Eloressa luultiin jo päästyn eroon, jatkuu. Olemme siltä osin samassa tilanteessa kuin vuonna 2005, jolloin lehden julkaisun jatkuminen oli vaakalaudalla, koska se oli käynyt liian raskaaksi toimittaa kokonaan talkoovoimin. Tieto julkaisutuen puoliintumisesta tuli keskelle uuden toimitussihteerin palkkausprosessia. Toivotamme Tiina Kaarelan tervetulleeksi Eloreen erittäin lämpimästi mutta samalla noloina, koska emme pystykään takaamaan tehtävän jatkuvuutta hakuilmoituksessa ilmaistuin ehdoin. Julkaisemme tämän kevään teemanumeromme ylpeinä, mutta samalla huolissamme tulevaisuudesta. Aluksi näytti kyseenalaiselta, voidaanko tämän vuoden syysnumeroa tehdä lainkaan, mutta onneksi SKTS:ssa kyettiin pika-aikataululla venymään sellaisiin erikoisjärjestelyihin, että syksynkin lehti saadaan ulos. Pyrimme jatkossakin julkaisemaan Eloren korkeatasoisena ja kahdesti vuodessa, mutta tulevaisuuden taivaalla on taas kerran tummia pilviä.

\section{ELOREN NUMERO 1/2009}

Eloren kevään numero on jo muutamina vuosina omistettu jollekin teemalle. Tämän kevään teemana on kulttuuriperintö. Haastateltavana on tuore kulttuuriperinnön professori, Outi Tuomi-Nikula Porin yliopistokeskuksen Kulttuurituotannon ja maisemantutkimuksen laitokselta. Pertti Anttonen puolestaan käsittelee kolumnissaan kulttuurin, perinnön ja perinteen toisiinsa kietoutuvia ulottuvuuksia. Teemaa lähestytään niin artikkeleissa kuin katsauksissakin monilta eri puolilta ja vaihtelevilta etäisyyksiltä - yhteistä niille on läheisyyden ja kaukaisuuden, tuttuuden ja vierauden samanaikaisuus. Useimmat kirjoittajat ovat jollain tapaa henkilökohtaisesti osallisina maantieteellisesti etäälläkin sijaitsevissa tutkimuskohteissaan: Jari Kupiainen pystyy kartoittamaan ryöstön kohteeksi joutuneen samoalaismuseon kärsimiä tappioita omien eriaikaisten inventaarioidensa pohjalta, Outi Tuomi-Nikula katsoo itäsaksalaista, muuttuvaa kotiseutuajattelua myös omien kotiseutukokemustensa kautta ja Tuomas Hovi on itsekin ollut tutkivana turistina Dracula-kierroksilla Transilvaniassa. Pekka Virtanen avaa katsauksessaan ikkunoita siihen, mitä folkloristi tekee tai voisi tehdä museossa. Toisen katsauksen on kirjoittanut perinnemusiikin tutkija Kai Åberg, joka analysoi romanien musiikkikulttuurin siirtymistä osaksi imaginaarista mustalaisku- 
vastoa. Artikkelien ja katsausten lisäksi tarjolla on jälleen alan tuoreiden tohtoreiden lectioita, lukuisia raportteja viimeaikaisista konferensseista sekä laaja näköala folkloristien, etnologien ja kulttuurintutkijoiden kannalta mielenkiintoiseen uuteen kirjallisuuteen. Aivan vapaasti sekä teidän että naapureidenne luettavissa, niin maistereille ja tohtoreille kuin kansakoulupohjaltakin, jos kiinnostusta riittää!

Me päätoimittajat esitämme sydämelliset kiitoksemme toimituskunnalle, joka teki taas kovasti töitä siitä ilosta, että saa olla mukana Eloren 15-vuotisella taipaleella; jokaiselle artikkelin, katsauksen, kirja-arvostelun ja ajankohtaisuutisen tai muun tekstin kirjoittajalle sekä kaikille anonyymiksi jääville referee-lukijoille! Päätoimitusvastuu jakautuu jatkossakin kahdelle tohtorille ja syksyn numerossa, joka siis ilmestyy sittenkin, päätoimittajina ovat Outi Fingerroos ja Petja Aarnipuu.

FT Petja Aarnipuu on tutkija ja tuntiopettaja Helsingin yliopiston kulttuurien tutkimuksen laitoksen folkloristiikan oppiaineessa.

FT Riina Haanpää on kulttuuriperinnön tutkimuksen päätoiminen tuntiopettaja Turun yliopiston Kulttuurituotannon ja maisemantutkimuksen laitoksella Porin yliopistokeskuksessa. 